\title{
A Queen's Drowning: Material Culture, Drama, and the Performance of a Technological Accident
}

\author{
Phillip Vannini \\ Royal Roads University
}

\begin{abstract}
Drawing on ethnographic data collected among residents of northwest British Columbia's coastal and island residents, I examine a technological accident: the sinking of the M/V Queen of the North. This accident is examined as an instance of social drama, as a succession of what Victor Turner calls breach, crisis, redress, and reintegration and what in this case I call wrecking, coping, inquiring, and mending. Ethnographic description, performative representation, and dramaturgic analysis of the sinking yield the impression that the Queen of the North was a person. Examined throughout this article are the performative processes through which the personhood and agency of this material object is accomplished. In so doing I posit an original dramaturgic approach to technoculture.

Keywords: material culture, technology, technography, personhood, technological accidents, dramaturgy
\end{abstract}

We feel and act about certain things that are ours very much as we feel and act about ourselves. -William James, The Principles of Psychology

\section{PROLOGUE}

\section{Early Spring 2006: On the Road between Victoria and Ladysmith}

Like other commuters, at times I drive sleepy, zoning out, perhaps too reliant on my automatic pilot mode. ${ }^{1}$ But today we are all wide awake. Two nights ago our Queen drowned. She lies in state, under hundreds of meters of freezing water. I keep glancing to the side of the road, down the cliffs, toward the ocean, to catch a glimpse of any floating signifier of routine and normality, but there is none, no ferries, and no rescue boats speeding up north to get her out of the water. Not even a kayak. I think to myself, "What are those fuckers doing leaving her there to rot?"

Direct all correspondence to Phillip Vannini, School of Communication and Culture, Royal Roads University, 2005 Sooke Road, Victoria, B.C. V9B 5Y2, Canada; e-mail: phillip.vannini@royalroads.ca.

Symbolic Interaction, Vol. 31, Issue 2, pp. 155-182, ISSN 0195-6086, electronic ISSN 1533-8665. ( 2008 by the Society for the Study of Symbolic Interaction. All rights reserved. Please direct all requests for permission to photocopy or reproduce article content through the University of California Press's Rights and Permissions website, at http://www.ucpressjournals.com/reprintinfo.asp. DOI: 10.1525/si.2008.31.2.155. 
As my eyes cautiously return to where they belong, my mind drifts again. A tear escapes. A second one is caught. I want to see what she looks like now. I want to understand what they did to her. How could they slam her body onto an island and drop her? How could they not see what was ahead? As I pull over to fill up, the gas-pump talk is about her, not the price of oil. "No, I've never been on her"-I answer the same question all day long with the same forlorn one-liner. Neither has the $\mathrm{CBC}$ radio anchor who keeps me company in the car on the drive home. Neither have some of the listeners who phone in to share their common memories and their wishes of seeing her again. Funny how you can miss somebody you never met, how you can grieve the loss of a machine. Funny how she doesn't feel like a piece of metal anymore. She was nothing but a good boat three days ago, and now she is our Queen, our one and only Queen of the North.

I am an islander. I live on the largest island off the Pacific Coast of the Americas: Vancouver Island. Surrounding my big "rock" are hundreds of smaller, sparsely populated islands and hundreds of uninhabited slabs of rock. Also, scattered all over the coast on the mainland between the two cities (Vancouver [pop. 2,187,721] and Prince Rupert [pop. 12,815]) are a handful of de facto islands: small fjord communities surrounded by ocean to the west and bounded on the north, east, and south by a looming, impenetrable chain of coastal mountains. All of the islands and coastal communities depend for their day-to-day survival on a vast network of three dozen ferryboats and as many routes.

For the past eighteen months I have turned to these boats not only as a passenger but also as an ethnographer. I study the interaction between us and our ferries as a form of drama. ${ }^{2}$ When you live on an island or remote coastal community your ferries play multiple, unique, and meaningful social and technological roles. I view technology as dramatic action and symbolic interaction: action and interaction that are ritualistic and the basis of community and culture (Carey 1989). The best word to describe this type of technology is technoculture: what people do together with things (Vannini, Hodson, and Vannini, forthcoming).

Most instances of technocultural interaction between humans and the devices they use-let us call the latter technics - are routine and habitual. We learn to rely on the roles that technics play daily. We tend to almost forget that these are but role performances. We suspend belief in the possibility that things might go wrong, that technics might deviate from their scripts. This suspension of doubt never goes away completely. Routine is always a form of drama (Lyman 1990): fragile, more or less suspenseful, habitual, mundane interaction that may be free of spectacular, histrionic, and melodramatic theatrical elements but that is nonetheless a profound illusion of order. Of course we know that as long as technics stick to their scripts, daily drama unfolds without a breach. Yet when a breach does occur, a new performance of that drama takes place: the accident. A technological accident, as a genre of technocultural drama, is something that people and machinery do together, and not just a technical issue. This writing is about that.

In reperforming an accident for you, I bring to your attention my version of how (rather than why) this accident, the sinking of the Queen of the North, occurred: as 
a succession of breach, crisis, redress, and reintegration (Turner 1988). The following performance highlights a set of theoretical ideas important to symbolic interactionists: the idea that technoculture is a form of dramatic action and that an accident is a discrete performance of that drama; the idea that personhood is diffused and not limited to humans, and that in the case of technics the genesis of personhood lies within a crisis-evoking wrecking; the idea that mobility is expressive, symbolic, interactive, and a form of techne; and the idea that agency is not a power that people have independently of the technics they use but a potential for action residing in the technics that make that action possible.

The present approach is also rich with methodological value: by employing a technographic strategy, I highlight ways to emphasize the meaningfulness of techne and technics, rather than ethnos alone. By using dramaturgy in the realm of technoculture studies, I extend dramaturgy as a research strategy and analytic perspective into new empirical territory. By employing a reflexive ethnographic and performative approach, I extend creative analytic practice into the realm of material culture and technology studies.

I base my performance on a year and a half of observations, introspection on six years of my life as an islander, forty field interviews, three Internet discussion boards, some fifty Web sites and blogs, and dozens of media texts (including media appearances of my own). Throughout the present performance, my role is that of a narrator and an actor (but not an omniscient director). This is partially performance ethnography and partially a short reflexive ethnographic story (see, e.g., Fontana 2002; Mitchell 2002), but I will call it technography (for more, see Vannini and Vannini, forthcoming; Vannini, Hodson, and Vannini, forthcoming). Technography is all those strategies combined: it is a way of writing about techne, about the social act of making as a form of artful craft and expressive action. My technography is a bricolage of dialogues, narratives, observations, and photographs that others and I have shared and collected. This strategy ensures that the storytelling is a collective act. There are no elements of fiction in any of the four acts-breach, crisis, redress, and reintegration - that make up the performance of the accident. "Reality" is messy, contradictory, and nuanced, and therefore choices for certain types of organization and order are nothing but that: choices, interpretive practices that allow me to make theoretical sense of the world that is no different from how the world is empirically experienced. Dialogues in the two closing sections are adapted from actual conversations and formatted to fit the academic and performative genre.

\section{THE BREACH: WRECKING THE QUEEN}

\section{Early Spring 2006: British Columbia's Central Coast}

"The Queen of the North cast off from Prince Rupert at 8 p.m. on March 21, 2006, with sixteen vehicles and 101 passengers aboard. ${ }^{3}$ The ship made a few scheduled stops along the way to small communities such as Klemtu and Bella Bella. 
During the off-tourist period the Queen of the North was an important link on the Central Coast of British Columbia, working as a supply ship, calling on various small communities in rotation each week. The route involved tricky navigation through islands and inlets south of Prince Rupert, then settled into the main waterway like Grenville Channel, north of Bella Bella. Transit through Grenville Channel took about two hours at sixteen to eighteen knots. The Queen entered Grenville Channel at around 10 p.m., travelling at a good service speed of about eighteen knots. Strong winds were reported of about forty to fifty knots with periodic bouts of heavy rain caused by squalls. Sea conditions were choppy, but visibility was good. These conditions were typical for the northern coast in early spring; however, it was a nasty night. The Queen of the North was designed for and used to sailing in much worse conditions. The ship made good through Grenville Channel. At the southern end of the channel, the crew of three on the bridge at the time, a senior deck officer, a junior deck officer, and helmsman, should have seen the flashing light of Sainty Point on the port hand. The Queen of the North exited Grenville Channel at around 12:15 a.m. A course correction, which brings the ship in line with Point Cummins, typically started at the exiting of Grenville Channel and continued through Wright Sound. Gil Island [an uninhabited island between Bella Bella and Prince Rupert] would be in the near distance, at the one or two o'clock position, or starboard bow. If all went well, the Sainty Point light would be directly to port as the ship exited Grenville Channel to transit Wright Sound. The Queen of the North did not make course correction and sailed directly towards Gil Island at full speed. The beach at this location had very little sand to buffer an impact, since this region of deep fjords had few diagonal or horizontal surfaces.

At approximately 12:26 a.m., having exited Grenville Channel and sailing through Wright Sound, she struck Gil Rock, near Juan Point, Gil Island, severely gashing the bottom of the hull. A loud bang and a nauseating grind of steel over rocks reverberated throughout the boat-then silence. Water filled the lowest parts of the ship as the crews below scrambled to safety. She sat on the rocks gradually listing starboard, moving about five degrees in about five minutes. She remained fast to the rocks that had her in their grip as water flooded in.

From the bridge, alarm bells and whistles sounded immediately. Over ear piercing alarms and bells orders were barked over the public address system to close watertight bulkheads, for crews to man stations, and for passengers to muster at lifeboat stations. The crew on the passenger decks dropped everything and leapt into action. The crew below decks, in the engine room, scrambled to escape the rapidly rising water.

A Mayday call went out and was also heard by citizens of Hartley Bay. At 12:28 a.m., the call was repeated to all stations in the region, by Prince Rupert Coast Guard radio, reporting the situation and the location of the ferry. The citizens living in nearby Hartley Bay (pop. 200) heard both radio calls and quickly went into action and lit up their houses. The women stayed ashore to tend to blankets, clothing, and meals for the incoming passengers and crew of the Queen of the North, while the men took to their boats and headed to the crippled ferry. 
The crew pounded furiously on each stateroom door rounding everyone up, to board the lifeboats. They checked every room, in an effort to locate everyone. Luck was on their side, as the ship did not move for a while, despite filling with water so quickly. During this time the Sir Wilfred Laurier, a Canadian Coast Guard light icebreaker that served as a coast station tender and patrol vessel, advised that she was preparing departure and dispatched a fast response boat. The captain, having assessed the grave situation of his crippled ship, gave the "abandon ship" order at 12:53 a.m., and all crew and passengers, mustered to life stations, began to leave the ship. The captain was the last person off the crippled vessel. The crew and passengers were safely off the ship about half an hour after the ship struck the rocks.

After an hour on the surface, the electrical system failed, the rising water flooded the engine room, and the ferry plunged into darkness. She could not stay afloat with the heavy burden of water flooding in. Reminiscent of the Titanic, her bow began to rise and her fixtures inside loudly crashed towards the heavier stern of the ship. The resulting air pressure blew out the forward windows-all sounds of painful agony from a ship at death. The passengers and crew who could see her, gasped in shock and sadness as the ferry tilted up eighty degrees and slowly sank. She slipped stern first, below the roiling waves around her and went to the bottom, resting in 450 meters of water upright, landing on a bed of silt and gravel. In a few minutes, the ferry vanished, leaving only stillness and the sounds of choppy water lapping against the life rafts and boats in the cold wet night."

\section{THE CRISIS: COPING TOGETHER}

\section{Early Spring 2006: Ladysmith}

I get home from school, rush to my home office, plug in, and log on. Looking for old pictures of her on the Net gives me little comfort; I need to see her the way she looks now. At least I think I do. Little do I know. "They’ve got pictures on TV!" April, my wife, hollers. I rush to the living room.

I don't know why, but that picture scares the shit out of me. ${ }^{4}$ I can't help wondering how others feel. I type in the URL of the Web discussion board that I've been hanging out in ever since I started doing research on BC ferries. I'm not the only one watching this on TV and reading the discussion board or posting at the same time.

"Eerie. That picture is spooky," writes BCGuy. ${ }^{5}$

Within seconds ComoxCaptain shows up, too: "It is hard to look at. I well up trying to look at that photo. It's just too hard." Ever since the Queen sank two days ago, well over two hundred messages have been posted on this thread. It's a cacophony of shock, sadness, and disbelief. That picture just made it worse.

"I'm having a hard time picturing what the passenger deck looks like right now. Everything onboard is ruined; the ferry is ruined. The Flagship of the Fleet is dead," writes VancouverIslander1968.

"Not being able to see the ship again really shocks me: the nice interior, sitting up front watching the TVs, sitting in the cafeteria on the side of the ship, standing 
on the back hearing the funnel sound like a jet, all sunken in water, I'll never get the chance to experience it again," replies 1972 BC.

Sadness is mixed with horror at the thought of her abject body. Spirit of BC writes: "I'm really curious as to how it landed on the bottom, and I have a feeling it didn't land in a nice upright state. But like you I hope that it didn't break in half." Schwartz-Bay-Admiral follows:

The Queen of the North has been on my mind all day, as I'm sure it has for everyone here as well. Someone reported this morning that it wasn't that far down, and the funnel was still sticking out of the water. So I thought, that's good then, maybe after a yearlong refitting would bring The North back to life. Now it's 600 feet down, she would have sunk fast once she was fully submerged, meaning she would have smashed on to the ground hard. Seemingly it was obviously dark out, there is the thought of the ship sinking, and all of the sudden the lights cut out because the generators were ruined, and The North was then a black powerless hulk being lowered to her grave. Then there's looking at the interior photos of her, and picturing how wrecked everything is now. All of the seats, walls, ceiling, floors, everything ruined.

Survivor and rescuer stories, old photographs, and television footage of her submerged carcass continue to pile up before me as my heavy eyes alternate glances between the TV and the computer. I learn that the decision not to lift her out of the water is now official. An empty-headed journalist from the big city adds that lifting "it" up and selling "it" for scrap would do the taxpayers a favor. Online ferry enthusiasts are of a different mind. Life@Sea erupts:

I hated having to watch that news story. There is a major problem with the media networks in our neck of the woods. No self-respecting news anchor, or for that matter human being, would refer to a lifeboat as a "safety boat." I for one am going to take a stand. Beginning now, here's how it's going to be: (1) The bow is called the bloody "BOW," not "nose"! (2) The stern is called the bloody "STERN," not "back"! (3) Lifeboats are called "lifeboats," not "safety boats." Honestly, you're living on the coast now. Get used to our "charming, backward ways," or get out. Last, but definitely not least: A SHIP IS A SHE, NOT A HE, IT, THING OR "PIECE OF JUNK"!!! GET OFF YOUR HIGH HORSES, YOU BUNCH OF WANNABE P.C. INTELLECTUALS, AND SHOW A VESSEL THE RESPECT SHE DESERVES!

Other posters, like Fisher65, agree with Life@Sea: "Rest in Peace, Queen of the North. Much better to be forever preserved at the bottom of the sea, than to be sent to the ship breakers."

\section{Late Winter 2007: Queen Charlotte City, Queen Charlotte Islands}

"You know what island time is?"

"Of course," I reply, feeling insulted. "I live on an island, man."

"You do," replies my drinking buddy for the evening, "but your island is different. Up here we never say 'I'm leaving tomorrow night at eleven' like you just did. Up here we say 'maybe I'll leave in the next few days."' 
The bartender laughs in agreement. That's a hell of an ethnographic insight, I think, as I thankfully order another White Russian for my informant. Island time stands for a lifestyle shared by many island dwellers who inhabit insulated spaces and time frames. Ferries are our floating clocks (Hodson and Vannini 2007), imposing their logic on our experience of time (cf. Altheide and Snow 1976), and every medium, every ferry, ticks at a different pace.

Sheila's letter to the editor of the Queen Charlotte Observer, reproduced below, captures the most quintessential aspects of island time. Sheila learned about island time in 2004 when she moved out here from a big city in Ontario. Back on the mainland her husband would get in trouble when he'd come back home from a grocery store trip without an item she asked for. He'd get in even more trouble when he'd justify himself with an excuse like: "I didn't forget the cheese; they just didn't have any." Sheila soon learned that those are plausible accounts here. If the ferry is late a couple of days, you learn to enjoy pizzas without cheese. Yet it and the ferry come back, eventually. But not this time. Sheila and the newspaper enthusiastically agreed to my desire to retell their story, albeit in condensed form. She writes:

Dear Editor, Sir: It has almost been a year in our present house. More like a cottage, this charming "boathouse" sports many leaks, frozen pipes when temperatures drop, and is definitely not insulated. Our house is situated on a rocky knoll hanging out over full-grown spruce, cedar trees, and the ocean. When you look down from our deck, you see the shoreline. We have seen risso dolphins, killer whales, gray whales, and countless birds through our windows. There is plenty of privacy considering how close we are to the ferry, although I often remind myself to close the curtains on dark early mornings when I get dressed in my room. I think what makes this house unique is its close proximity to the ferry and the interesting relationship I have developed with its coming and going.

I know the ferry schedule better than most on the island, and have spent many a night watching with wonder as the ferries pull in to dock. Mornings are bright and early as I hear the intercom announcing the ferry arrival vibrating through my bedroom wall. The reefers hum, keeping me awake some nights; they remind me of the city sounds from my past life, a postal truck waiting in front of my house. I think of the excited sounds of people waiting for late night ferries, kids crying or laughing, dogs barking and occasional music rhythms, all drifting up to us.

Last week we returned from our March break ski trip to the mainland. We were excited to see friends and children who were busy running around reacquainting themselves. Idle chat among friends touched on strange topics relating to the ferry. How wonderful the Queen of the North ferry was when compared to our older Rupert ferry. One time the ferry slowed down and idled for a few minutes. We wondered, what might be wrong, were we going back? We chatted about how safe this ferry was.

This Monday morning, I awoke to the familiar sound of the arriving ferry and traffic moving off. I checked the time and noted that it was early; the ferry was on time and the weather good. Great I thought, we can grocery shop after school, by then food will be on the shelves. The next morning was the same. I know the schedule so well, I set my daily activities by it, and get my weather forecast directly from looking out determining when the ferry will arrive. I even 
set my runs by it, heading out to Skidegate as the ferry blows its horn to announce departure. I have tried racing the ferry, me on land, and it out on the water. The ferry wins every time, but I continue to try and beat it.

Wednesday morning, I awoke to the sound of the phone ringing, it was my friend Pam whose calm but tight voice told me the Queen of the North sank last night. I could not believe it. I looked out my window, remembering the site only a day before: a clean white and blue smoke stack filling up my window view. From this point on, our community went into a state of shock and disbelief. I was in town that morning, helping with my daughter's class trip and encountered so many staring faces looking into my eyes searching for some recognition and understanding of what has happened. We came together, people headed to town, simply to be with others, to look into their eyes and share. We are sharing the countless questions that are circling our minds. It could have been us last week, and all the children from March break. Who was on it? Were they all rescued? What about my friends, Judy and James, and their children? They were supposed to be returning by ferry from Port Hardy any day now. Why were there only two lifeboats and do they not hold all the passengers? Would they have held all of us last week? Where are the family pets? What about the nice fellow who worked in the cafeteria, or the people who helped us position our cars: familiar faces, like the ones you see at the local coffee shop. I wonder how long the lights stayed on. I think of the seat I sat on only five days ago, the gift shop, and the artwork hanging on the walls. I know the paintings well, especially the one with the proud portrait of the ferry itself. I picture the ferry at the ocean bottom, the play area, the cafeteria, and all those cars.

This ship cannot sink; it was the good one, the safer one. How will we get our supplies? The other ferry is in for repair. People went crazy today, our dear friends who would do anything for us. We all rushed to the stores to get the last food. People filled grocery carts with milk; some took milk from other people's carts. It was chaos. Hermits, rarely seen, came out of the forest to buy milk. It is strange to look out my window and see the empty port, then listen to the news from the "outside world" to find out our destiny. Everything seems so far away from us here. A six year old boy says, "Mommy, do you mean the arcade room is at the bottom of the sea?" "Yes," she says. Too much for a little mind to take in. Ode to our ferry, a ship that filled our bay, its coming and going a constant mark on our horizon.

\section{Early Spring 2006: Somewhere on the Web}

They found her. A small submarine just located her, and pictures are becoming available.

"It is sitting on the keel (amazing) and is deep in silt; some places it comes up to the rubbing strake," Mark writes to the discussion board in jubilation.

"She's intact!" exclaims Howe_Sound_King.

An unregistered guest logs in: "She's in one Piece and Upright!"

"Good, she didn't suffer too much then!" says QueenGrandma, beaming a euphoric smiley.

My heart warms up. As Russ puts it: "She'll have that 'frozen in time' look. Majestically ploughing through the sea bed, rather than laying on her side like a beached whale." 
Mark agrees: "I am so glad she landed upright and in silt. At least she is still for the most part in one piece and not all beat up. Kind of like she is still sailing under the water. To The North!"

"It is time to raise our glasses," interjects ScubaKing, followed by others, many donning tear-filled emoticons.

"To The North! Let's hope that we can find her and lay a wreath to a ship that will now only live in memories."

"Yes, to the North!! To a beautiful ship, that had a great service life!"

"To the North. Rest in peace!"

\section{REDRESS: INQUIRING AS CAUSE-TALK \\ Late Winter 2007: Cruising through Grenville Channel on the Queen of Prince Rupert}

"It's so stupid how BC Ferries advertise this route as some kind of a cruise, isn't it?" says a middle-aged man to his female companion at the breakfast table, loud enough for me and the few other souls in the almost empty forward dining lounge to hear.

"Yeah, they should advertise it to the tourists with a big ugly picture of your sleepy-assed face stuffed with the Sunshine Breakfast!" she responds, knowingly loud. They chuckle. I do too. A couple of other bystanders can't help it either. Everyone's eyes make contact, free of signs of eavesdropping embarrassment. On a boat like this you can hardly keep private about anything. There are only forty or so passengers after the drop-off at Bella Bella, and if you're going all the way to Prince Rupert you have a whole twenty-four hours to do nothing, unless you're an ethnographer who needs to write field notes or a kid with spare change and mad arcade skills. There are neither phones nor cell-phone reception. No Titanic-like orchestra. No saltwater pool on the sundeck. And there are no books good enough to compete with the humbling scenery of unnamed snowcapped peaks towering one after another in endless succession, an infinite wall of trees, the possibility of spotting bears, whales, or porpoises on either side of the channel, and the endless play of guessing how deep inland the next fjord can reach. By the time you reach port you've drunk a lot of coffee and met and spoken with everybody about everything, especially about the ferries, everyone's favorite topic.

As noon nears, I equip myself with a local map. We are close to Gil Island. The sun is out, and I decide to make my way to the stern early. Smokers and camera lovers alike welcome me.

"How good is that map?"

"It's pretty detailed," I answer.

"Does it show Gil Island?"

"It's right here on it, but you can actually see it forward to port side if you lean out a bit. To about ten or eleven o'clock." 
They walk over to the railings, then turn around: "That's IT? How the fuck do you miss THAT?" the younger one remarks to me. Immediately, other people join in.

"Oh, is that Gil Island? Let me see."

"We're here already? I'd better go get Steve out." Soon a crowd forms.

"So, what do you guys think happened?" a young logger from Vancouver on his way to the Charlottes asks the motley crew. A disorderly chorus of speculations begins.

"Didn't they say they were having sex on the bridge? That helmsman and the helmswoman, right?"

"Yeah, and they shut off the navigation control panel lights so that no one could see them humping."

"There's no way you could have sex on the bridge; you'd have to be an idiot to try."

"Right, I don't think they were having sex; but they were partying. When they radioed in for help and every time they radioed Rupert before that you could hear music really loud."

"No matter what they did, it's negligence on their part."

"Yeah, it's not the responsibility of a ship to make a course correction!"

"Yep! There was nothing wrong with the vessel. Nothing wrong with the equipment."

"I read in the paper they were on automatic pilot and when they realized they were off course they didn't know how to disengage it."

"Yeah, the helmswoman didn't."

"They wouldn't wanna be on automatic pilot through the channel here, though, would they?"

"But automatic pilot or not, how do you miss that? I don't care how stormy and how dark it was; the Queen had all sorts of gadgets to get through these waters safely."

"Nah, that's a bunch of conspiracy stuff, the reason why she sank is because she was an old boat and had single compartments."

"What? That doesn't make any sense! Yeah, she didn't, but so what? That doesn't have anything to do with why they rammed her into an island."

"Yeah, that's the crap that's been going around in Victoria to score some political points against the Liberals, and besides, and not that I'm taking the Liberals' side, but that's the way they made ships back in those days. It doesn't have anything to do with the Queen. She was old, but she still was the best damn ship they had."

"Yeah, no matter what actually did happen, it was human error, and we gotta live with that."

"Yeah, we can all agree on that; there's no way with the radars, the GPS, the alarms and bells going off on the bridge when you go off course that it could be mechanical failures. That stuff was new. They probably didn't know how to use it."

"Yeah. Could it have been because of the weather though?"

"No way, it wasn't that bad for North Coast standards, and the North was made for that kind of rough sailing and she was used to it."

The chorus continues for a bit, then the freezing wind finally mutes it. 


\section{REINTEGRATION: MENDING WOUNDS BY REMEMBERING}

\section{Late Winter 2007: Queen Charlotte City}

Queen Charlotte City is colder than I imagined. It's not the puff of brittle, windswept March snow that catches me by surprise as I hurry my pace to find lee after my interview with the mayor, but it's the remote, frozen feel that its streets, waters, and buildings ooze. As I rush back on my way to one of the three-perhaps two by now at this "late" time in the mid-afternoon-java holes in town, my eyes capture a glimpse of an abandoned late-1980s Chevy truck lying lonely on a grassy knoll, likely someone's backyard. Things don't get thrown away thoughtlessly on these islands. But if they must go, they don't go to waste. They go to rest somewhere, awaiting recall. When you live on a remote island you keep everything around for spare parts. The outcome of that conservationist outlook is in everyone's sight. Pragmatic monuments to bygone needs, waiting in reserve for future craft and artful make-do, such as rusted boats, mangled cars, sleepy fire engines, dot-without littering — bushes, side roads, and hidden bays. Discarded technologies on the street help you never let go of memories.

Other, more ephemeral, textual traces are at jeopardy for falling into oblivion: fleeting images of seeing the Queen cruise by; ethereal wishes-like mine-for trips that never came true. One day here on the coast we'll ask one another where we were when we heard the Queen sank. I'm reminded of Coast_To_Coast 1980, who wrote on the Web discussion board:

On the morning of March twenty-second I woke up and turned on the TV. What
I saw saddened me instantly. The words that I read on the screen were "BC ferry
sinks on north coast." Right away I knew it was The North. Later in the day as I
watched the news I knew that we would never see that ship in service ever again.
Now all we have are memories and pictures of this amazing ferry whose life was
tragically cut short. Take a minute and don't talk or do anything, just sit and re-
member this great ferry, for people that have been on her remember the experi-
ence and for those who haven't been on her try to remember how much of a
good ferry she was. It's sad to see BC Ferries' flagship die in such a sad way, but
when she was in service she was known as the "Queen of the north coast." Even
though she is gone she will always be the flagship of BC Ferries. Rest in Peace
Queen of the North. You will be missed but not forgotten.

Memories about her stuff my unkempt field journal. Like IslandLife1970's, who remembers "playing deck chair races with friends; put two deck chairs on the side and let the wind push the chairs to the back of the ship. First chair to hit the aft railing won." Or like Down_With_The_White_Spot, who remembers learning "Tai Chi in the evenings from Willi Ho on the aft deck outside the restaurant." And Captain@Heart, who finds that "working on a live-aboard vessel is a unique experience, co-workers quickly become 'family' and the ship becomes 'home." He continues: "Our home is gone now but it will always be in our memories." 
Childhood memories are the most painful to evoke. In Prince Rupert I collected the story of Kent Glowinski. After the sinking, he opened his heart to readers of the Globe and Mail. ${ }^{7}$ He wrote:

With the sinking of the Queen of the North off Prince Rupert, down went not just a ship, but parts of my childhood. I think of family vacations on the vessel. I can still feel the nauseating rocking of the ship as it plowed through the night. I can still see the small porch lights on the coastal mainland as we passed through the Inside Passage. I can still taste the potato chips from the one vending machine-the one that was sometimes working. My family, like many other northern mill-worker families, could not afford four round-trip tickets on an airline from northern BC to Vancouver. And so the four of us, mom, dad, my brother and I, would pile into Grandma's (loaned) Winnebago and sit in line, waiting for the distant wail from the Queen of the North's horn. I remember the excitement of running up the stairs to the passenger deck, waiting for mom and dad to fish out quarters out of their pockets, bribing my younger brother and me to go to the arcade room as they dozed on the plastic seats with their stale ferry-cafeteria coffee in hand. BC Ferries would always advertise vacations by ferry with smiling tourists, killer whales, and glowing sunlit water. But they never showed the families, like mine, eyes circled with bags of exhaustion, Winnebago packed with canned foods, babies crying, and the slight odour of motion sickness. No one ever slept. Instead my brother and I would sneak out of the room and secretly run around the ship. The Queen of the North was like an unexplored labyrinth: the staircases to state rooms, the doors leading to nowhere, the bathrooms sealed with metal doors. I would run from bow to stern, passing sleeping families, under café tables, through the Pacific Lounge bar, and back to the arcade room to challenge my brother to Pac Man. If I close my eyes, I can almost see the Pac Man arcade game blinking like a lone beacon at the sea bottom. I can see the abandoned cars and trucks on the vehicle deck, stuffed with pillows, blankets, and suitcases. And the Winnebagos, dirty dishes from an early evening dinner floating amid the dense, dark seaweed. Ferries, it would seem, permeate the mythology of northern BC. While I don't think this ship will ever get a motion picture named after it, or be forever remembered through old wives' tales or urban myths, it will nonetheless be a part of my story; the story about a middle-class family, in a Winnebago, in Prince Rupert BC, me with a pocket full of quarters, a Pac Man arcade game, and Vancouver Island on the horizon.

Months later, stories of commemoration of her loss are as plentiful and touching. Like Graham's, who left his home in late March 2007 to travel on his own pilgrimage on the Q.P.R. as she sailed by Gil Island precisely one year after the Queen's death. Photographs are ubiquitous, too, posted on Web sites as homage and mnemonic tools. Graham has some of the most beautiful.

As I lay aside my bulging field journal to start browsing the media scrapbook put together by Dawn-who is known among friends as the Queen of the North-a sheet jumps at me: "Queen of the North song." My latte cools off as I slowly pore through the newspaper article. The song was written in memory of the Queen of the North and performed in April of 2006 on the first voyage of the Q.P.R. after the Queen's sinking. The author is Clive Quigley - a Vancouver Island resident and BC 
Ferry worker for over twenty years. He was quite shaken by the sinking, so he wrote a song and performed it for the B.C. Ferry and Marine Workers' Union meeting. The room went silent. People cried their hearts out. After that he was invited to perform it for the memorial they had on the Q.P.R. The local paper here ran a story on that.

\begin{abstract}
Aboard the Queen of Prince Rupert, with cloud-shrouded Gil Island as a sombre backdrop, Edward Dahlgren threw white roses into the gunmetal-grey waters of Wright Sound in B.C.'s Inside Passage yesterday. The flowers thrown by Dahlgren, a ferry captain and marine superintendent for the North Coast, landed above the final resting place of the Queen of the North, more than 400 meters below. Ninety-nine white roses were tossed over the side of the Queen of Prince Rupert just after dawn, one for each survivor of the March twenty-two sinking. Two red roses were also put in the water for passengers Gerald Foisy and Shirley Rosette, who are presumed drowned. Crew and passengers gathered on deck as the ferry halted for the brief ceremony. Ferry officer Clive Quigley sang "Song for the North," which he wrote after the sinking, and strummed his guitar eight times-for eight bells, signifying the end of one ship's watch, and the beginning of another. As the Queen of Prince Rupert floated above the sunken ferry, Capt. Orval Bouchard read a message over the public address system: "When sailors first set out to sea, we do it with full admiration of the sea, and with a heart full of ambitions, with no thoughts whatsoever that this beautiful sea could be our worst enemy. The Queen of the North has sailed up and down the Inside Passage for 26 years-and for the years untold, we will sail over her, and we will remember her, and the two missing souls forever."
\end{abstract}

Clive sings his song a capella:

Could anyone know when her last day would be?

Southbound from Rupert to Port Hardy

She sailed so long, "Pride of the Fleet"

Now she's alone, so cold and deep

On a moonless night, when the stars were hidden

Harsh wind and rain with seas forbidding

She stayed upright till her crew was safe

And with a final breath slipped beneath the waves

Now the hardest time all sailors know

Is to watch your ship as she sinks below

For a piece of your heart and a piece of your soul

Has somehow lost its anchor-old

God bless our friends from Hartley Bay

Angels sent crashing through the spray

God bless our friends who heard the call

The bravest sailors of them all

We loved "The North," she was our own

So fast and clean, we called her home

Our flagship, of so fair and fine

And she'll always sail on our union sign

She'll sail forever on our union sign. 


\section{DRAMA, MATERIALITY, AND PERSONHOOD \\ Early Spring 2007: Somewhere on a Ferry on My Way Back Home from Vancouver}

"Always late; this ferry's always freaking late!" the middle-aged woman seated to my right complains to her husband. She gets a nod and a monosyllable. Unsatisfied, she turns to me: "At least you bring your work on, eh?" She receives another uninterested nod. Normally I wouldn't hesitate to start up a field conversation, but today I'm not in the field ... er ... actually I am, but not to collect data. I'm in the field accidentally: I just needed to get some business done in Vancouver, and my laptop is with me because I need to focus on writing up, and not on taking, notes. Five seconds of silence go by. I feel guilty.

"You go to the mainland a lot?" I ask to resuscitate the conversation I just suffocated.

"Twice a month to visit family. This ferry is the road to my mom's home in North Van. What are you writing about?" she asks me.

"I'm writing about people like me and you taking the ferries and the role that the ferries play in the drama of everyday life."

"Oh, really? What do you mean by role? Like economic?"

"No, I mean dramatic role. Like a performance, with scripts, with actors that play them with a set of prescriptions for what goes on in a scene," I answer, thinking that by sounding pedantic and academic I'll kill the conversation again.

"You know, I have a theater background," she tells me. Suddenly the conversation begins to sound more appealing. "So," she continues, now with a more captive audience, "are you writing a play?"

"Actually right now I'm working on writing the theory part of a paper focused on technology as material culture. I'm writing about the idea of a script and I'm applying it to the study of interaction between humans and material objects."

"Sounds neat. Is that a common thing in your field, to think of objects like that?" "Well, in technology studies, some scholars (Akrich 1992; Latour 1988) have been writing about manufacturers inscribing their visions of consumers' use of objects into the design of objects themselves. I'm playing with that idea a bit. I'm making the argument that we can think of ferry boats, for example, not only as being inscribed a technical function but actually being assigned scripts for the ritual performance of their roles. When things and their users interact, those scripts may or may not be followed, and other scripts and new roles may be created."

"That makes sense to me," she reassures me, detecting that I'm nervously looking for signs that I'm making myself understood. "You know, in a way," she continues, "this boat has a very important set of roles in my family life. And what's interesting at least from a dramatic point of view is that she plays different roles in different people's lives, and they are often changing, don't you think? For my husband, for example, this boat is an enemy; it's what stands between him and the game on TV, though this has changed over time. He's from eastern BC and at first he used to think 
of it as a getaway, a trip off 'the rock.' For my teenage children this was their weekend play-buddy when they were little kids. But now it's changed. This boat is what stands between my duty as a parent to supervise them and their urge to throw parties while we're gone. In a way sometimes I wish this boat was early at least for one time; I have a feeling that then I would really catch them kids red-handed!"

"Yep," her husband interrupts her, "this boat is a partner in crime for my kids and a thief of my time!"

Visions of potential use surely may be inscribed into the material design of technics, but the actual performance of their scripted roles is emergent and contingent on setting, the action of all the actors involved (technics included), and the particulars of dramatic action and ritual. The same technical actor, even when it is given only one basic script such as the transportation of people and goods across water, has as many roles as the people it interacts with on that stage. This approach borrows from two related ideas. First, Carey (1989) has argued that we should think of all technics as social actors. He makes the example of technics acting as tricksters in everyday life. Tricksters promise order but instead wreak havoc. His is a good argument. But I feel that regardless of the actual role they play-trickster, accomplicetechnics may come off in certain scenes as more than simply actors playing a role. Indeed I believe that they can come off as persons. The second existent idea that I'm stretching is that of objects working as extensions of self (Belk 1988). A boat, like many technics, becomes an extension of the self when personal significance for the user's self is attributed to her. "A man's self is the sum total of all that he can call his, not only his body and psychic powers, but his . . house . . lands . . yacht," writes James (1890:291-92). "Valued material possessions . . act as signs of the self that are essential in their own right for its continued cultivation"-writes Gene Halton (1984:335), more recently- "and hence the world of meaning that we create for ourselves, and that creates our selves extends literally into our surroundings." The Queen was a symbol of us as dwellers of this coast. But she was more, too.

\section{Late Winter 2007: Somewhere on a Ferry on the BC Central Coast}

Personhood is not inherent in subjectivity but acquired "from moral rules that are impressed" from outside the person (Goffman 1967:45). As a result of what has been impressed on her, the Queen of the North acquired a dramatic veneer of human nature and personhood as she wrecked and sank not too far from here. As an outcome of that process she went from being merely an extension of self and from being merely an actor playing a role to being a person: a "socially defined publicly visible embodied being" (Harré 1984:26). Cahill (1998:135) explains an important difference between persons, individuals, and selves: as opposed to persons, individuals are "organic bodily beings"; selves are beings with "reflexive awareness of personal agency and identity" (emphasis added). Nonhuman technics can be persons but not selves or individuals. The Queen's accident was the performative genesis of her personhood. 
I have to be careful with this point; I can get so excited about my ideas. I need to stop writing. I put my laptop down for a minute and sink my teeth into a date square - my favorite ferry food—and start thumbing through my notes, hunting for printouts of an e-mail exchange I had with my friend and colleague Dennis Waskul last week. He was cautiously skeptical about my excitement even then. I reflect on his insightful message one more time. It reads: "Wouldn't it be safer to say that The Queen of the North is personified? Treated as a sacred object? Don't forget what Chuck Edgley and Kenneth Burke wrote. From a dramaturgic perspective there is an important 'difference between a thing and a person' (Edgley 2003:149). That difference is that 'things move-people act'" (Burke 1966:53).

Dennis is right, but I want to put a twist on that, too. So, do me a favor, dear reader. Imagine being here seated near me not as an ethnographer but as a local, like one of those folks over there, on their way back from a grocery store that is eight hours away, lying on the hard floor trying to put their little kids to sleep for the night. Put yourself in their shoes: the shoes of someone who lives in a remote coastal community only accessible by floatplanes or ferryboat. OK, now think of what becomes really important in a situation like that: mobility. And what's basically the only thing that can guarantee you that? A ferryboat, just like this one. She brings groceries, medicines, furniture, toys, mail, family members, tourists, and their money-you name it. She makes your world go around. What I'm getting at is this: mobility is central to embodied interaction and material culture in general, but it is especially important in a situation like the one I just described, our coastal and island culture. Mobility is the most quintessential expression of technoculture. Mobility is techne: the embodied and material performance of expressiveness. Mobility is the primary expression of all of our motor and sensory habits: from the streaming of a tear to the wake of a ship, mobility is mediation of material and embodied being.

Insofar as they make certain types of action possible-like human mobilitytechnics are agency. Agency may indeed be something that one has, but to say that one has something does not explain what that something is. From a dramaturgic perspective, agency is something that an actor does in the course of action. And how can one do anything, that is, exercise agency, without any means? Technics, like boats, are agency in the sense that they are means through which situated action takes place. They are agency insofar as they have the potential to make action possible. Remember Burke's (1962) pentad of action? For him an act was a deed. The scene of an act is the situation in which an act takes place. The purpose is the objective of action. To explain action "you must indicate what person or kind of person (agent) performed the act [and] what means or instruments he [sic] used (agency)" (Burke 1962:xvii). Agency is diffuse, context dependent, and relational. Agency is also most evident not in abstract conceptions of free will but in performative contexts. Such contexts "display and tap into [an expression] of agency that is assumed to transcend the particular individuals present and the temporal moment in which they act" (Keane 1997:7). Agency is "socio-culturally mediated capacity to act" (Ahern 2001:110) and may involve-in different roles-humans, spirits, machines, 
animals, and signs. And who knows, maybe more. These things are the mediation, and without them there is no capacity. So in the end a ship is a kind of person, and she is also the agency that humans have to move across water.

After all this, would you still say that mobility is that much less significant than action? "A critical component of human action is expressiveness," you might reiterate. "Humans must be expressive, they must engage in conduct. But nonhuman objects? How can they be expressive?" you might argue. But here's my point: there can be no meaningful expressiveness outside interaction with other social actors. Expressiveness is not the outward conveyance of a force that lies within. Expressiveness is an emergent product of collective social action, not its cause. It is something that must be "enacted and portrayed, something that must be realized" (Goffman 1959:75). After all, dramaturgy "is not primarily interested in what people do, nor what they intend to do, nor even why they do it, but how they do it" (Brissett and Edgley 1990:3). So, yeah, the Queen of the North has no consciousness, intentionality, motivation, symbolic reflexivity, selfhood, or the will to communicate. But she is agency and she is material. On the basis of her agency and material appearance (see Stone 1975) she is assigned meanings, roles, a personal identity, and even status as a person. Her sheer materiality is a peg on which her personhood is hung, just like it is for human persons (cf. Goffman 1959:253) by those with whom she interacts. "Interaction," writes Owens (2007:570), "does not require that both parties willingly and purposefully engage with one another ... nor is it required that both parties be able to symbolically interpret and share meaning."

The Queen is not organically alive, but she is socially alive. As a "biographical object" (Morin 1969) she has a localized, biographical, and distributed identity. Her localized identity emerges from her relation to a particular space, this coast. With her mobility she both limits and expands the spatial freedom of its passengers and shapes their experience of time while mooring her symbolic anchor into our cultural waterscape and harboring our collective identity. Her biographical identity comes from her moving across time over the years, from her growing old together with her passengers. Her distributed identity comes from sharing her bodily mobility and identity with that of its users, from being her users' "everyday experience[s] made into a thing" (Morin 1969:138). Now, keep in mind that this is but a good start on the way to personhood, but these sources of "personal identity" - to borrow from Goffman (1963:57) - may not be enough in and of themselves to warrant the status of person. Moreover, a person is more than simply the actor of a role (Cahill 1998). Evidence of style or "expressive identifiability" (Goffman 1974:288; also see Cahill 1998:137) is necessary for personhood.

Rather than in reflexivity, personality, or free will, the Queen's identifiability necessary for personhood can be found in the "expressive means of person production [contained] in folk psychologies and revealed in discourse" about her and in how people interact toward her (Cahill 1998:137). Different scenes and their respective role performances and rituals may be the occasions of personhood diffusion to different material objects and technics. Personhood—as distinct from mere role acting-is 
especially likely to arise when the same actor plays the same role over time, when the actor's role adequacy is high and consistent, when the actor and its/his/her social circle are intimately connected by strong bonds of affiliation, and when a role is conspicuously representative of a role system and the organization that it represents (Turner 1978).

So the Queen doesn't need to be reflexive to be a person. Her unique ways of performing her scripts for mobility, both routine and accidental, are sufficient in her case. Keep this in mind: "There is absolutely nothing in the expressive or impressive dimension of life that requires any consideration whatsoever of cognition, volition, deliberation, or intention" (Edgley 2003:145). Persons after all are nothing but $o b$ jects of "collaborative manufacture" (Cahill 1998:130) and outcomes of interactional labor (Goffman 1967) rather than fleshy human beings. "Individuals"-Cahill (1998:132) wrote- "may be the material objects in which persons are imbedded, but persons are not inherent in bodily individuals." The Queen's personhood is not inherent or essential in her. It just comes off scenes of interaction such as the ones described in this article, given to me by the folks who interacted with her, who knew that she wasn't just a piece of junk, or that she could be replaced by another actor for her role. Her status as a "social person" (Gell 1998:125) then comes from the chaining together of these people's dramatic routines, their "everyday encounters with the material world" (Mitchell 1998:391), and the violation of that routine by way of a violent rite of passage: the accident.

\section{THE ACCIDENT AS DRAMATIC PERFORMANCE}

\section{Early Spring 2007: On the Air at a Regional Radio Station}

Mark: "It's been precisely twelve months since the Queen of the North sank in the Inside Passage, but memories of the accident still haunt many of us here on the coast. To talk about that day and the events that followed it, here with us is Phillip Vannini from Royal Roads University. Thank you for joining us this morning!"

Author: "Thank you for having me."

Mark: "Your research on technological accidents like the Queen of the North's sinking shows that accidents have unique characteristics. Tell us about it."

Author: "Well, Mark, people tend to act toward technological possibilities as given on a daily basis. In other words, over time the operation of complex machines and tools seems less and less complex and chancy and tends to become taken for granted, like the performance of a routine social role that we all blindly rely on. As long as that role is performed in line with expectations, nobody pays much attention to the potential fragility of that routine. But when a technic, like the Queen of the North did, deviates from the script she has been assigned, we get into a whole new dramatic production of reality and a whole different performance."

Mark: "Dramatic? You mean, like the kind of drama we would see at the theater?" 
Author: "Precisely. When role deviations occur we have a breach of routine interaction (Turner 1988). Just like human beings, material objects have social lives of sorts. An accident is a drastic turning point (Glaser and Strauss 1971) in the life of an object, and a breach is the first stage of that process. It is a transformation pregnant with significant consequences for the future of the wrecked object's life and a threat to its social and material continuity. A breach is a turning point in the life of an object's users, too. Accidents are often thought of as brief events, but if we think of them as social performances we can think of the breach of routine as a climax and of all that follows as the unfolding plot."

Mark: "So, a breach is always the beginning of a social drama?"

Author: "According to anthropologist Viktor Turner (1988), yes. Now, in the particular case of technological accidents a breach is a wrecking of some type: an explosion, a leak, a crash, or in this case a shipwreck. This is not only a turning point in the life of the objects and its users but also a mutation and 'recontextualization' of the object's life in the sense that interaction with these objects now unfolds in nonroutine forms (Thomas 1989:49). I like to call these climactic events wreckings because they're a unique type of breach. After they have happened something is spoiled or broken; there is a 'status passage' (Glaser and Strauss 1971) from functional to useless, at least in the routine instrumental sense."

Mark: "OK, but what about breaking a glass in the kitchen? Or what about a boat that breaks and that is simply replaced without much hoopla? Are those wreckings too?"

Author: "No. Those breakpoints that you mentioned don't seem to generate a crisis. A wrecking is qualitatively different. A wrecking is a rite of passage in the sense that the loss it represents heightens the dramatic conditions in which a new status, and new relations, need to be created. In a way, a wrecking is like the opposite of a rite of passage, like an initiation, but the process is similar, since it is a ritual marking the transformation of a social actor, and relations among actors, from one status or identity to another."

Mark: "How can a one-time thing like an accident be a ritual?"

Author: "Students of culture who use a dramatist perspective suggest that after a breach three more phases unfold: a crisis, a redress, and a reintegration (Turner 1988). Those are the four phases of social dramas in general. Now, drama is a property of life: an ongoing ritual process that exists regardless of whether a particular dramatic performance happens once or routinely. So, the event in consideration may be a one-time production, but the structure of that production is ritualistic. In the case of the social performance of technological accidents the structure comprises a wrecking, as I already said, and then following acts that we can call coping, inquiring, and mending."

Mark: "So we can think of the role of Queen of the North as a very important one."

Author: "Well, her role is obviously very important, but what really stands out for me in this case is the fact that over time she acquired a social status of her own which went beyond that of mere actor of a role. It is almost as if the special way in 
which she performed her role made her stand out as a person (see Turner 1978). Her identity as a boat, different from all of our ferries, contributed to giving her this aura of personhood. Some people up and down the coast would consciously plan their trips to take her specifically. Others knew that when the waters were really choppy she would be the only one able to sail. When the royal family came to visit our coast, it was the Queen who was chosen to take them on a cruise to Vancouver. She performed any role with grace, efficiency, courage, and class. So in a sense while her abstract role was important, she-as a person performing that role-was truly distinct and significant."

Mark: "So, even though she wasn't a human being, she came off as a person."

Author: "Yes. There is a certain way in which we attribute personlike characteristics to things, especially to means of transportation. You can say we anthropomorphize them (see Gell 1998). This is not uncommon for ships. For starters, ships seem human and even have regal names. So, they're not just common persons, they are VIPs. And secondly they receive a gender, like many other material objects do. That makes it easier to talk about them as if they were human. They are not human persons, but in dramatic action they come off as if they were."

Mark: "That's true. Many refer to her sinking as her death, a tragic demise of an old lady."

Author: "Yes, her wrecking gave her the status of personhood. If you read accounts of the wrecking you'll find many instances in which bodily metaphors are used to describe her status passage from a functional machine to an abject body. That status passage revolves around her body, and our bodies, our feelings, and lived memories. The body is always at the center stage of incidents in the drama of everyday life (Goffman 1967; Waskul and Van der Riet 2002). During the wrecking, the Queen's body loses control of itself, usurping her image of a graceful person, threatening to spoil her identity. Words like 'crippled,' 'painful agony,' are very common in many descriptions of the wrecking. And interestingly enough it seemed almost as if she resisted the stigma of wrecking and threat of abjectification. In many descriptions of the event she comes off as if she put up a courageous and tenacious fight: first to hang tight to the grip of the rocks just long enough to let her passengers off, and then to stay afloat despite her injured limbs."

Mark: "So in a few words, the Queen of the North was a person with a body?"

Author: "A nonhuman person with a nonorganic body, indeed. This is not an entirely new idea. In many occasions the lines between nonorganic objects and people are blurred. Sometimes human persons seem to take on the role of physical objects, and physical objects seem to take on the role of persons (Hoskins 2006). The basic idea behind this is that technology is culture and action; it is about doing social things with ... well, social things. When we look at technology as action we see how people distribute significance and even personhood to things in the process of interacting with them. The aura of some objects is almost magical; it's like a form of enchantment (Gell 1988). Things aren't just props."

Mark: "Following the breach we have a crisis, right?" 
Author: "Yes. People begin to cope with the loss of a person. If we think of her as an extension of our self, not only an individual but also a collective self, it follows that her loss is the loss of part of our collective self, of one of us. So the crisis comes from her death: an interference with our sense of continuity in collective being, a deep 'violation of the person' (Simmel 1950:322) that we care about so much."

Mark: "You know what is truly fascinating to me? I lived all my life in central Canada where the only ships that enter people's imagination are cruise ships. And they're great for a holiday, but as I moved out here a couple of years ago I realized that a ship is an islander's best friend."

Author: "That is one of the most difficult things to convey to an audience who lives far away from here. People, especially mainlanders, tend to see a ferry as an alternative to a bridge. But islanders are very passionate about that distinction. Ferries in a way are boundary objects (Star and Griesemer 1989); locals act toward them as symbols that express our difference from other, distant communities. Each ferry is a boundary object, too. The BC Ferries fleet counts about three dozen vessels and each has its own community, its own identity. When a ferry—especially our flagship—dies, it truly seems like a part of all of us has passed away. For outsiders this is difficult to understand, but for us it's part of our life, of who we are. Put it like this: people everywhere express strong attachment to their homes, the possessions within their homes, and their neighborhoods (see Belk 1988). For many of us the Queen was all of that."

Mark: "That explains why the story received little attention elsewhere, but why we were so deeply touched."

Author: "Well, there is no way of knowing for sure what people experience. In dramatic terms all we can know is what social actors express. And what I do know is that many local individuals have played a central role in the dramatic performance of the accident. They have done this by coping in intense ways, even unbelievably so at times, especially considering that this was, after all, a material object that they neither owned nor possessed."

Mark: "What's the significance of expressing grief in this case?"

Author: "The death of the Queen was no minor incident. Her demise was a loss of something that was sacred. I like to hijack words from William James (1890:293) — who wrote so eloquently about the loss of material objects—and say that now all that remains of the Queen is 'a sense of the shrinkage of our personality, a partial conversion of ourselves to nothingness.' As people went out of their way to publicly commemorate her tragic demise, the plot of the social drama shifted to a new act: the building of a shared narrative (Katovich and Hintz 1997). At first the narrative was a way of making sense of the wrecking itself. For example, many amateur webmasters took to the Internet to try and re-create the incident to account for it. At the same time the public sharing of narratives-whether by talking about the ship with friends and family, or more publicly by discussing shared experiences on the Web, or by writing letters to the editors of newspapers-worked by shaping a common past (see Katovich and Hintz 1997). 'Object loss is the fountainhead of creativity,' Russell Belk (1988:143) once said.” 
Mark: "So, by sharing stories people created a sense of community?"

Author: "Yes. Communication is always a way of creating communitas of feeling, by way of partaking in ritual (Carey 1989; Turner 1988). By storytelling people created a shared experience of memories of the Queen of the North and a sense of her community, our community. It is interesting how even after her status passage to a wrecked object she continued to bring people together, if not physically at least emotionally. Telling stories and creating that narrative experience is dramatic action that builds a tie between people."

Mark: "In a way it felt as if the people affected were a large family that had lost their home, or even a family member that lived in their home, if we think of the coast as a common home."

Author: "Yes, that's why the thought or the images of her abject interiors and exteriors seemingly upset so many people. Common objects help build a shared past (Katovich and Hintz 1997). Narrating their loss is a way of reconstructing them, if not materially, at least symbolically. We depend on our ferries. We're the kind of people who say we hate our ferries, but more than anywhere I've lived, I feel that I'm around people who are very deeply attached to our place and deeply attuned to our common expressions of attachment toward it. So just like a hammer extends our arm strength, or just like a pair of binoculars extends our vision, a boat not only extends our body's ability to move across water, but it also restricts outsiders from moving in, and extends our bodily sense of who we are and our emotional attachment to one another. For us islanders our ferries are like a "mirror through which we view ourselves' (Belk 1988:146)."

Mark: "Do you think that people felt that the Queen was given due respect?"

Author: "I've noticed a lot of dramatic moves to save the Queen's face after her demise."

Mark: "Face? Did I hear you right?"

Author: "A face is basically the positive social value that is claimed for or by a person (Goffman 1967). A human being has a face to defend in conduct with others. A ship can't do that for herself, but that doesn't matter too much: actors are committed to saving the face of others in certain circumstances (Goffman 1967). This is especially the case with technics that are deeply significant. In certain cases objects are outright inalienable from persons. People can be very upset when someone else's face, especially a person they deeply care about, is threatened. When the Queen sank, it was potentially a shameful situation for her, an embarrassing scene for all of us. Her reputation as our safe and efficient vessel, which was designed and used for those treacherous waters, was at stake. I'm not saying that the ship could ever feel shame, but because she was so meaningful and so esteemed by many, her 'dignity' was on the line. Shame is contagious (Goffman 1967). Some journalists weren't too sensitive to this. They made a political issue out of something people didn't immediately perceive as political."

Mark: "You mean the issue of her being old and consequently the government being questioned because they had not replaced her earlier?" 
Author: "Yes. We all knew she was old and nearing the time when it was best for her to retire, but for some of the media from our urban and political centers to raise this issue hours after the wrecking, without appreciation and understanding of her past here on the coast, made the Queen come off as if 'it' was a piece of meaningless junk unable to be on the water."

Mark: "Absolutely. And that was perceived as disrespectful."

Author: "Yeah. It was a matter of dignity. Coping with a wrecking is not just about expressing the significance of the wreck, but in this case it was also about expressing emotional identification with the person who suffered the wrecking. People do not enjoy having to witness the defacement of persons whom they care about. After incidents like this you see instances of people protecting the face of others. A face is sacred, and coping - as a series of public emotional moves-is a delicate ritual that expresses the sacredness of a person's face."

Mark: "After the first few days, or maybe even weeks, all the talk about the Queen seemed to shift. It is almost as if there was no drama anymore, or at least no tragedy. A lot of what there has been is a search for the causes and the culprits. Is that what you call the phase of inquiry?"

Author: "Yes. There still was drama and suspense, however, only a different act within that dramatic performance. It was like a who-done-it part of the performance. Inquiring is a form of action directed at rationalizing a wrecking. When the Queen sank, people began to account for the incident. This is typical of many social circumstances: when routine action is interrupted, social actors will attempt to account for that interruption (Scott and Lyman 1975)."

Mark: "And some of the causes, or the accounts, seem to be more plausible than others."

Author: "And that's where so much of the dramatic action is: in identifying villains and in pointing out probable causes. So here is what's interesting about this: the audience is made of those who determine what causes are more or less true on the basis of how appropriate they seem. We don't really have ultimate causes after an accident like this. Instead we have vocabularies of causes."

Mark: "A vocabulary? As in a set of definitions and interpretations?"

Author: "Yes: competing definitions of the situation surrounding the wrecking. To say that after she sank people began to employ a vocabulary of causes is not the same thing as to say that people began the work of finding the true cause. When people break norms or go against expectations, we generally try to account for why they did it: we form quasi-theories (Hewitt and Hall 1973). When technics break away from the routine performance of their roles, we do something similar by accounting for their deviation from their script: we impute technical causes to the malfunctioning of the objects involved, and we account for the behavior of the human actors involved. So in studying the drama of an accident, we should probably be more concerned with the formulation and expression of vocabularies of causes than with technical causes."

Mark: "Interesting! So, what do you make of the malicious rumors that go around?" 
Author: "Vocabularies of causes are tailor-made in the society in which dramas unfold. Regardless of whether or not it is true-and we will never know for sure-accounting for a wrecking like this by pointing out the presence of a woman at the helm as the originating cause behind sexual distraction, inability to pilot, and moral looseness in the bridge draws from many easily available sexist frames."

Mark: "And I guess at the same time the ship was again protected from absorbing the blame. Those who dared to point out the age issue were quickly silenced."

Author: "Yes, exactly. In general you could say something as simple as this: when a technological accident unfolds, you'll witness three main types of vocabularies of causes. One type is the class of circumstantial accounts, like environmental obstacles, etc. The weather was nasty that night, but do note how everyone has been pretty much in agreement that the Queen was experienced and tough enough to handle it. A second type is technical causes. In other words, issues that relate to the way technics carry out their roles. Again, because she was so dear to all, no one will account for her wrecking by claiming that she was a piece of junk. And last, you have the category called human error."

Mark: "And everyone by now is pretty much in agreement that it was human error in this case."

Author: "Yes, isn't that interesting how well that claim works in this setting? Inquiring is a form of redress in the sense that you'll see social actors trying to align their actions with one another to reestablish the regularity of social interaction. Inquiring is talk, and therefore a form of action. Think of any accident and think of the endless sequences of accounting talk surrounding it. It is a critical component within drama."

Mark: "So, OK, if I get this right, then by agreeing that human error is the cause, we're actually enacting another act in the plot; we are creating villains and imputing a villainous act to them?"

Author: "Yes. What we have is an ad hoc explanation of this technological accident. We have quasi-theorizing that attempts to bring definitive knowledge into the cause of an accident. But it does nothing but bring a sense of order and hope for future solutions. We have cause-talk."

Mark: "So we have nothing but quasi-theories which in this case point to human error ..."

Author: "Yep. Human error, in the case of a technological accident, is a type of excuse (cf. Scott and Lyman 1975). No one will deny that the wrecking was undesirable, but all parties involved seemed to believe that there was no intention of causing it."

Mark: "Yes, it is after all an accident and not a premeditated act."

Author: "Indeed. And if we want to be precise in this case, we have at least two different categories of human error that have been batted around. We have witnessed appeals to technical incompetence-for example, appeals to the inability to disengage the automatic pilot-and appeals to negligence, which is typical of vocabularies of 
causes that point to crew messing around on the bridge or smoking pot before boarding the vessel. And what all of these appeals and all of this cause-talk do is save the face of the Queen of the North!"

Mark: "OK, so I think we are now to the last phase, the mending, right? What is that?"

Author: "Within dramas you will always see a tendency toward reintegration, order, and appeasement (Turner 1988). That doesn't mean that reintegration will always occur, but the tendency is still there. In the case of the social drama of a technological accident we have mending action, which is basically action directed at healing wounds."

Mark: "Like the replacement of the Queen with another vessel and the implementations of the recommendations of the National Transportation Safety Board?"

Author: "At the very least, yes. Those forms of mending ensure that the technical role that underwent the wrecking will continue to be performed by appropriate actors. But mending action is directed at providing final reintegration for all those who struggled to cope with the loss of the Queen. Mending action is ritual performance directed at historical reconstruction of an event and the persons involved within it. Mending is a form of public drama (Gross 1986)."

Mark: "Performance like in the writing and performance of songs about her?"

Author: "That's a great example. The ritual of recollecting and publicly sharing recollections is productive of personhood (Merrill 2007). Songs, the creation of memorial Web sites, the writing of letters, the sharing of pictures, pilgrimages, conversations, the observance of the passing of time-as in anniversaries, et cetera-and the sharing of memories is what mending is all about in this case: the construction and reconstruction of a person's reputation. All of these forms and media of communication are ritual creations of community. These expressive acts work by preserving the integrity of the Queen's character and by reinforcing memories. By remembering her, we shape a material symbolic of our collective memory. And once again by remembering her, by expressing how we got to know her, we are once again engaging in a rite of 'transformation' (see Mitchell 2006) whereby she ceases to be a mere abject material object and she becomes a prized social subject worthy of our attachment."

Mark: "So the dramatic action here resides in performing the past?"

Author: "Yes, and by performing memories of the past, people of distant coastal communities come together symbolically. By sharing stories about our ferries, we continuously root our biographical past. These are historical public dramas: expressive actions whose main outcome is the recognition of an important event and the creation of a significant memory (see Gross 1986)."

Mark: "In a way, that's exactly what we're doing right now, you and I and our audiences ..."

Author: "Yep. We are continuing her 'lifecycle' (Mackenzie 1991) by further tying her with our sense of regional identity. We're demarcating her as a 'history object' (Hoskins 1993) by talking about her. And that's precisely what my research does. Accident-ing, or performing an accident, is a way of extending the self of individuals and 
collectives so as to encompass meaningful material objects and technics. In performing an accident, even simply by writing about it, I'm actually contributing to shaping the personhood of a wrecked object. I'm part of that drama. You at home and in your offices are, too, simply by being our audience."

Mark: "In the end, I guess, forget 'God save the Queen.' We are the ones saving her, eh?"

Author: "Yep. Not people and their accidents, but accidents and their people (cf. Goffman 1967:3).”

Acknowledgments: I would like to thank Graham Johnson, John Hammersmark, Sheila Karrow, Paul Keenleyside, Dawn Quast, Alex Rinfret, Dennis Waskul, Carol Rambo and her four reviewers, as well as everyone on the BC ferry forum. Above all, April Vannini made this work possible by dissecting and scrutinizing, and thus improving, each and every one of my observations and ideas. This article is dedicated to the memory of Gerald Foisy and Shirley Rosette, who perished on the fateful night of our flagship's sinking.

\section{NOTES}

1. The reader is invited to consult additional features (map, pictures, acknowledgments) on the Symbolic Interaction Web site, http://researcher.royalroads.ca/si, under "communications > SI discussion."

2. My research investigates the role played by ferryboats in everyday life of coastal British Columbia (BC). The data this article is based on are only a subset of the larger project.

3. The following section is a description of the sinking authored by Paul Keenleyside, an informant. The account is in his words (save minor edits), not mine. Like many British Columbians, Paul posted an account of the event-written by collating available media and official reports-on his Web site to commemorate the loss of the ship and two passengers. I contacted Paul to request permission to reproduce his Web log in condensed and edited form for this article, and he granted me his approval and offered help and suggestions. The original log can be found at http://modena.intergate.ca/personal/pl8s/IP/QoTN/IP_QTN.htm. I have opted not to indent or italicize his writing because I feel that both options would have improperly relegated his account to the margins and distanced it from my writing. Yet to recognize that those are his words, I use quotation marks.

4. See this and other pictures on the Symbolic Interaction Web site (see note 1).

5. Handles have been changed to protect anonymity. The forum is accessible for both posting and reading, yet I still opted to notify discussion board participants of my research, shared drafts of my article with them, and invited feedback.

6. Adapted from the March 26, 2006, issue and reprinted with permission of Sheila Karrow and the Queen Charlotte Observer.

7. Adapted from the March 23, 2006, issue and reprinted with permission of the Globe and Mail.

\section{REFERENCES}

Ahern, Laura. 2001. "Language and Agency." Annual Review of Anthropology 30:109-37.

Akrich, Madeleine. 1992. "The De-scription of Technical Objects." Pp. 205-24 in Shaping Technology/Building Society: Studies in Sociotechnical Change, edited by W. E. Bijker and J. Law. Cambridge, MA: MIT Press. 
Altheide, David L. and Robert P. Snow. 1976. Media Logic. Beverly Hills, CA: Sage.

Belk, Russell. 1988. "Possessions and Extensions of the Self." Journal of Consumer Research 15:139-68.

Brissett, Dennis and Charles Edgley. 1990. Life as Theater: A Dramaturgical Sourcebook. New York: Aldine.

Burke, Kenneth. 1962. A Grammar of Motives and a Rhetoric of Motives. New York: Meridian Books.

1966. Language as Symbolic Action. Berkeley: University of California Press.

Cahill, Spencer. 1998. "Toward a Sociology of the Person." Sociological Theorv 16:131-48.

Carey, James W. 1989. Communication as Culture: Essays on Media and Society. New York: Routledge.

Edgley, Charles. 2003. "The Dramaturgical Genre.” Pp. 141-72 in Handbook of Symbolic Interactionism, edited by L. Reynolds and N. Herman-Kinney. Walnut Creek, CA: AltaMira.

Fontana, Andrea. 2002. "Short Stories from the Salt." Pp. 201-18 in Postmodern Existential Sociology, edited by J. A. Kotarba and J. M. Johnson. Walnut Creek, CA: AltaMira.

Gell, Alfred. 1998. Art and Agency: A New Anthropological Theory. Oxford: Oxford University Press.

Glaser, Barney and Anselm Strauss. 1971. Status Passage: A Formal Theory. Chicago: Aldine.

Goffman, Erving. 1959. The Presentation of Self in Everyday Life. Garden City, NY: Doubleday. . 1963. Behavior in Public Places. New York: Free Press. 1967. Interaction Ritual. New York: Pantheon Books.

1974. Frame Analysis. Harper and Row.

Gross, Edward. 1986. "The Social Construction of Historical Events through Public Dramas." Symbolic Interaction 9:179-200.

Halton, Eugene. 1984. "Object Relations, Role Models, and Cultivation of the Self." Environment and Behavior 16:335-68.

Harré, Rom. 1984. Personal Being. Cambridge, MA: Harvard University Press.

Hewitt, John P. and Peter M. Hall. 1973. "Social Problems, Problematic Situations, and QuasiTheories." American Sociological Review 38:367-74.

Hodson, Jaigris and Phillip Vannini. 2007. "Island Time: The Media Logic and Ritual of Ferry Commuting on Gabriola Island, BC." Canadian Journal of Communication 32:261-75.

Hoskins, Janet. 1993. The Play of Time: Kodi Perspectives on Calendars, Exchange, and History. Berkeley: University of California Press.

. 2006. "Agency, Biography, and Objects." Pp. 74-84 in Handbook of Material Culture, edited by C. Tilley, W. Keane, S. Kuchler, M. Rowlands, and P. Spyer. London: Sage.

James, William. 1890. The Principles of Psychology. Vol. 1. New York: Holt.

Katovich, Michael and Robert Hintz, Jr. 1997. "Responding to a Traumatic Event: Restoring Shared Pasts within a Small Community." Svmbolic Interaction 20:275-90.

Keane, Webb. 1997. Signs of Recognition: Powers and Hazards of Representation in an Indonesian Society. Berkeley: University of California Press.

Latour, Bruno [Jim Johnson]. 1988. "The Sociology of a Door Closer." Social Problems 35: 298-310.

Lyman, Scott. 1990. "The Drama in the Routine: A Prolegomenon to a Praxiological Sociology." Sociological Theorv 8:217-223.

Mackenzie, Maureen. 1991. Androgynous Object: String Bags and Gender in Central New Guinea. London: Harwood.

Merrill, John B. 2007. "Him: Remembering the Person." Svmbolic Interaction 30(4):495-500.

Mitchell, John. 1998. "Performances of Masculinity in a Maltese Fiesta." Pp. 68-92 in Recasting Ritual: Performance, Media, Identity, edited by F. Hughes-Freeland and M. M. Crain. New York: Routledge.

. 2006. "Performance." Pp. 384-401 in Handbook of Material Culture, edited by C. Tilley,

W. Keane, S. Kuchler, M. Rowlands, and P. Spyer. London: Sage.

Mitchell, Richard. 2002. Dancing at Armageddon. Chicago: University of Chicago Press. 
Morin, Violette. 1969. "L'object biographique." Communications 13:131-39.

Owens, Erica. 2007. "Non-biologic Objects as Actors." Svmbolic Interaction 30(4):567-584.

Scott, Marvin B. and Stanford Lyman. 1975. "Accounts." Pp. 171-91 in Life as Theater: A Dramaturgical Sourcebook, edited by D. Brissett and C. Edgley. Chicago: Aldine.

Simmel, Georg. 1950. The Sociology of Georg Simmel. Translated by K. Wolff. Glencoe, IL: Free Press.

Star, Susan L. and James R. Griesemer. 1989. "Institutional Ecology, 'Translations,' and Boundary Objects: Amateurs and Professionals in Berkeley's Museum of Vertebrate Zoology, 1907-1939." Social Studies of Science 19:387-420.

Stone, Gregory P. 1975. "Appearance and the Self." Pp. 78-90 in Life as Theater: A Dramaturgical Sourcebook, edited by D. Brissett and C. Edgley. Chicago: Aldine.

Thomas, Nick. 1989. "Material Culture and Colonial Power: Ethnological Collecting and the Establishment of Colonial Rule in Fiji." Man 24:41-56.

Turner, Ralph. 1978. "The Role and the Person.” American Journal of Sociology 84:1-23.

Turner, Victor. 1988. The Anthropology of Performance. New York: PAJ.

Vannini, Phillip and April Vannini. Forthcoming. "Of Walking Shoes, Boats, Golf Carts, Bicycles, and a Slow Technoculture: A Technography of Movement and Embodied Media on Protection Island, BC." Qualitative Inquiry.

Vannini, Phillip, Jaigris Hodson, and April Vannini. Forthcoming. "Toward a Technography of Everyday Life: The Methodological Legacy of James W. Carey's Ecology of Technoculture as Communication. Cultural Studies $\leftarrow \rightarrow$ Critical Methodologies.

Waskul, Dennis and Pamela Van der Riet. 2002. "The Abject Embodiment of Cancer Patients: Dignity, Selfhood, and the Grotesque Body." Symbolic Interaction 25:487-513. 